\title{
Reseña del libro: Sarlé, Patricia M. y Rosemberg, Celia R. (coords.) (2015): Dale que... El juego dramático y el desarrollo del lenguaje en los niños pequeños Rosario: Homo Sapiens.
}

por Nora Grinóvero (1)

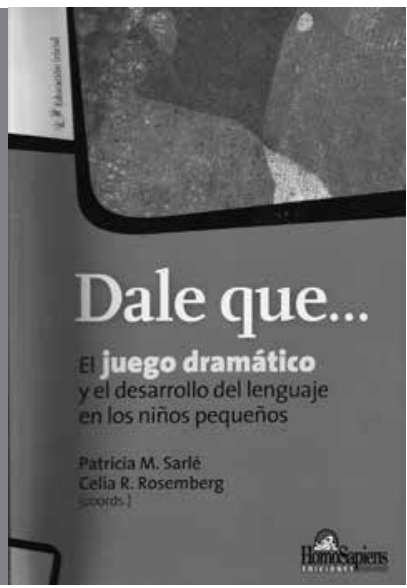

Patricia Sarlé y Celia Rosenberg, coordinadoras de la publicación, conforman

(1) Docente FHUC-UNL un equipo en el que se potencian dos trayectorias con sus preocupaciones, la primera desde el juego y la segunda desde el lenguaje, y logran transmitir valiosísimos aportes para pensar las prácticas en la educación inicial a la vez que transparentan su compromiso con los niños y la educación. Dale que... El juego dramático y el desarrollo del lenguaje en los niños pequeños es el título que eligieron para presentar sus estudios, reflexiones y propuestas, donde la figura del maestro es su principal interlocutor. Las investigaciones en las que ellas han participado son el sustento de muchas de sus afirmaciones y de los aportes que brindan en esta producción. ${ }^{(2)}$ Juego y lenguaje, dos grandes mandatos de la educación inicial, siempre presentes a la hora de planificar, aunque pocas veces se constituye en objeto de reflexión el sentido con que se presentan en las prácticas de enseñanza, más allá de la espontánea inclusión que el niño hace de ellos en el ámbito escolar. A este respecto, las autoras afirman:

(2) Lenguaje, Juego y Enseñanza en la Educación Infantil (UBACyT) y El juego en el Nivel Inicial, Propuestas de enseñanza (Área de apoyo a la Educación Inicial de la OEI), son algunas de las investigaciones de referencia. 
«Aun cuando parezca que el juego y el lenguaje son omnipresentes en la vida cotidiana del Jardín, ello no quiere decir que alcance con que los niños jueguen y hablen para promover su desarrollo. Las situaciones de juego y lenguaje deben ser objeto de diseño de las prácticas y necesitan ser tematizadas en la formación docente. La relación entre el juego y lenguaje es crítica para la educación infantil» (168).

En este libro se ocupan de la resistencia que el jugar le pone a la escuela y la escuela al jugar, la importancia del juego en la educación de los niños pequeños, los modos de incluirlo en los tiempos y los espacios educativos, la relación entre juego y lenguaje, las potencialidades del juego dramático en el desarrollo del lenguaje y las experiencias en contextos socioculturales diversos. Aportan categorías de análisis, reflexiones y desafían a pensar propuestas potentes, pertinentes y de calidad. Enriquecen esta producción con una serie de registros y relatos de escenas de juego en salas de escuelas infantiles y en otros escenarios que ilustran y facilitan la comprensión de los conceptos y las ideas que plantean.

Además, reconocen el valor de la escuela como el espacio donde los niños aprenden a relacionarse, a dar sentido al mundo, a ser sensibles frente al otro y sus diferentes modos de expresión; esto es aún más significativo en el contexto actual puesto que, por diversas razones, se juega poco dentro y fuera de ella. El texto se organiza en dos partes: la primera está centrada en el aspecto didáctico del juego en la educación inicial y la segunda ofrece un análisis de la relación entre el juego y el lenguaje.

En el primer capítulo, «Didáctica y Juego», Patricia Sarlé enfatiza en la centralidad del juego como contenido de enseñanza, tal como lo define la Ley Nacional de Educación 26206; superando su lugar de método para enseñar o el de una actividad más de la jornada escolar. Ella dice: «definir el juego como contenido supone comprender qué se enseña al jugar». En este sentido avanza en algunas precisiones en torno a los modos de mediación del maestro para cada tipo de juego y ofrece un marco posible sobre y para la acción pedagógica en las salas, que permitan hacer crecer al juego, profundizar, avanzar y consolidarse en los niños «tal como se espera que suceda con cualquier otro conocimiento que se pretenda enseñar» (25). 
Desde esta perspectiva, el juego pasa a constituirse en una responsabilidad del educador en la previsión de situaciones, materiales, espacios y tiempos propios. Como marco de referencia, hace un recorrido por la relación entre la educación infantil y el juego, resalta que los grandes pedagogos de la infancia desde los precursores hasta la actualidad han coincidido en la importancia del jugar. Desarrolla, entonces, tres cuestiones centrales: ¿cómo definimos al juego en la educación infantil? ¿Por qué es importante jugar en la escuela infantil? ¿Qué caracteriza un «buen juego» en este marco? Y retoma aportes de Bruner, Baquero, Huizinga, Pavía, Brougère, Agamben, entre otros.

Sarlé afirma que el juego es un mediador cultural al permitir al niño pequeño desprenderse del aquí y ahora y entrar en el mundo simbólico, en el mundo de lo representado, y siempre abre al otro, el compañero, el amigo, el cómplice, el contrincante, que es integrado en el jugar. El valor educativo del juego, radica en la experiencia del jugar.

Reconoce, a la vez, que no tenemos un saber específico, un saber acerca de la transmisión del saber jugar que permita al maestro durante el juego recuperar sus propias matrices lúdicas, apelar a sus experiencias infantiles y descubrir cómo reconocer en los niños los motivos por los que juegan de una manera u otra.

En el segundo y tercer capítulo, la misma autora se aboca específicamente al juego dramático, resalta que compromete la función simbólica que permite utilizar símbolos y con ellos representar; abre la posibilidad de aprender a partir de imágenes mentales, de ahí la importancia de su desarrollo. Cuando los niños asumen un papel social ensayan sistemas simbólicos de significados, con el soporte de un guión dramático que van sosteniendo y construyendo en el transcurso del jugar.

Brinda propuestas, ideas, conceptos para comprender cómo se enseña a jugar dramáticamente, donde el tema, los roles o papeles, el escenario, el guión y las intervenciones del docente como jugador son aspectos centrales que favorecen el enriquecimiento del juego.

Con aportes de coautoras, investigadoras como Lila Pinto, Elvira Pastorino, Inés Rodríguez Sáenz y Verona Batiuk, contextualiza la propuesta a través relatos y análisis de proyectos desarrollados en salas de jardín de infantes en México y en varias provincias argentinas, e incluyen la reflexión sobre la práctica de las docentes. 
En la segunda parte del libro, Celia Rosemberg se ocupa de la relación entre el lenguaje y el juego dramático. Sostiene que los conocimientos, las habilidades y los comportamientos que se desarrollan durante la socialización están moldeados por el lenguaje y, a la vez, ellos son «el motor» para que el lenguaje se desarrolle. Esto fundamenta la idea de que en la escuela infantil el lenguaje es tanto objeto como medio de enseñanza.

Rosemberg, en autoría compartida con Josefina Arrué y Maia Migdalek, realiza un análisis acerca de cómo los niños desarrollan y enriquecen el lenguaje a través del juego, emplean un lenguaje explícito, descontextualizado y con una sintaxis relativamente compleja, construyen discurso narrativo y también crean mundos de ficción.

Ellas expresan conclusiones de sus estudios donde analizan al lenguaje como andamiaje en la transición y la creación de la ficción, «del mundo real al ficcional y de este al mundo real».

Sostienen que el nivel inicial puede encontrar en el juego dramático un medio poderoso para potenciar el desarrollo lingüístico de los niños pequeños con el objetivo de favorecer su transición hacia la escuela primaria.

Presentan resultados de estudios muestrales en los que concluyen que los tipos de juegos, modo de participación de los niños y las personas que los inician y acompañan en los juegos difieren según los contextos socioculturales de procedencia, así como las estrategias utilizadas en secuencias argumentativas que desarrollan los niños para sostener sus puntos de vista.

En el Epílogo, Sarlé y Rosemberg sintetizan las ideas más importantes sobre juego y lenguaje en la educación infantil, destacan el lugar de la escuela como responsable de ampliar la experiencia del niño y lo fundamentan diciendo:

«La cognición, el contexto social y el lenguaje están entrelazados en las situaciones de juego. El conocimiento se crea y se recrea a través del lenguaje, en los intercambios que mantienen los niños mientras participan en el desarrollo del juego. En las interacciones que constituyen la trama lúdica, el niño va también adquiriendo el lenguaje. En efecto el lenguaje se aprende a través del uso del lenguaje; jugando se aprenden palabras, se aprenden distintos tipos de discurso, se aprende a narrar, a describir, a explicar, a argumentar» (168). 